\title{
DROUGHT TOLERANCE OF FOUR VEGETABLE CROPS DURING GERMINATION AND INITIAL SEEDLING GROWTH
}

\author{
TOLERÂNCIA DE QUATRO ESPÉCIES DE HORTALIÇAS AO DÉFICIT HÍDRICO \\ DURANTE A GERMINAÇÃO E CRESCIMENTO INICIAL DAS PLÂNTULAS
}

\author{
Fábio STEINER ${ }^{1}$; Alan Mario ZUFFO ${ }^{2}$ \\ 1. Professor, PhD., State University of Mato Grosso do Sul - UEMS, Cassilândia, MS, Brazil. steiner@ uems.br; 2. Professor, PhD., \\ Federal University of Mato Grosso do Sul - UFMS, Chapadão do Sul, MS, Brasil. alan_zuffo@ @otmail.com
}

\begin{abstract}
Seeds of arugula (Eruca sativa Miller, cv. Cultivada), carrot (Daucus carota L., cv. Nantes), eggplant (Solanum melongena L., cv. Embú) and watermelon [Citrullus lanatus (Thunb.) Matsum. \& Nakai cv. Crimson Sweet] were submitted to different osmotic potentials induced by polyethylene glycol (PEG) with the objective of evaluate the effects of drought stress on seed germination and initial seedling growth. Seeds were distributed in plastic boxes containing blotter paper, soaked with PEG solutions prepared with osmotic potentials 0.0 (control), $-0.2,-0.4$, and $-0.8 \mathrm{MPa}$ and kept into a seed germinator, at $25{ }^{\circ} \mathrm{C}$ for 14 days. A completely randomized design in a $4 \times 4$ factorial scheme with four replicates of 50 seeds each was used. The results showed that by increasing of the osmotic potential level, germinated seeds number, germination rate index, root and shoot length, shoot and root dry matter, and seedling vigor indices decreased, while mean germination time and root: shoot ratio increased in all four vegetable crops. Additionally, the carrot and watermelon are more susceptible than arugula and eggplant to drought stress, with germination response declining more rapidly with the rise of osmotic potential level. Arugula and eggplant crops tolerate water stress of up to $-0.2 \mathrm{MPa}$, without reducing germination of the seeds; however, the growth of shoots and roots are inhibited. The germination process of eggplant and watermelon seeds are completely inhibited at $-0.8 \mathrm{MPa}$ osmotic potential, whereas germination of carrot seeds is completely inhibited at $-0.4 \mathrm{MPa}$ osmotic potential. Severe drought stress limits the process of seed germination and initial seedling growth of vegetable crops.
\end{abstract}

KEY WORDS: Eruca sativa. Daucus carota. Solanum melongena. Citrullus lanatus. Osmotic potential. PEG 6.000.

\section{INTRODUCTION}

Drought is one of the most significant environmental stresses causing huge loss to the agriculture around the world. Vegetables are more sensitive to drought when compared to many other crops. Rapid and uniform field emergence are essential prerequisites to increase yield and products quality (SIKHA et al., 2013). Frequently, adverse environmental conditions led to a slow and nonuniform emergence, resulting in an unevenness in the stand establishment. Therefore, to ensure the food supply for a growing world population, studies that aim to mitigate the detrimental effects of drought and identify crop species with higher tolerance are extremely important for horticultural crops research.

Seed germination and seedling establishment are potentially the most critical stages in the life cycle of plants for water stress (HU et al., 2015). Water availability and movement into the seeds are very important to promote germination, initial root growing, shoot elongation and therefore at the establishment of a uniform stand. The germination process starts with seed imbibition as result of water uptake (BEWLEY et al., 2013). This process occurs due to difference in water potential between the dry seed and water in the substrate of germination. However, the base water potential required for germination varies greatly among species (GEORGE et al., 2013), especially because of the chemical composition and tegument permeability of the seeds (BEWLEY et al., 2013). Highly negative osmotic potential may affect the seeds water uptake, making germination not possible (MENESES et al., 2011). The most common responses of plants to reduction of osmotic potential are a delay in initial germination and a reduction in the rate and total germination (SIKHA et al., 2013; JATOI et al., 2014; GORDIN et al., 2015).

One of the most commonly methods used to determine the tolerance of plants to water stresses is the evaluation of the germination capacity of seeds using aqueous solutions of polyethylene glycol (PEG) under laboratory conditions (MENESES et al., 2011; GHAROOBI et al., 2012; GEORGE et al., 2013; JATOI et al., 2014; BASHA et al., 2015). 
Polyethylene glycol with molecular mass of 6,000 or more are non-penetrable and non-toxic osmotic substance which can be used to lower the water potential of the germination environmental and it has been used to simulate controlled drought stress in nutrient solution cultures. Many studies on plant responses to drought stress induced by PEG solutions with regard to seed germination and seedling growth have been recently reported, including studies of agricultural crops, barley (GHAROOBI et al., 2012), common bean (AGUILAR-BENÍTEZ et al., 2014), sunflower (LUAN et al., 2014), lentil (MUSCOLO et al., 2014), sesame (MEDEIROS et al., 2015), maize (GHAROOBI et al., 2012; AGUILAR-BENÍTEZ et al., 2014), cotton (MENESES et al., 2011) and wheat (JATOI et al., 2014). In contrast, few reports have focused on horticultural plants, even though vegetables are shown to be more sensitive to drought than many other crops.

This research was carried out to evaluate the effects of drought stress induced by polyethylene glycol (PEG) on seed germination, growth and vigor of arugula (Eruca sativa Miller), carrot (Daucus carota L.), eggplant (Solanum melongena L.) and watermelon [Citrullus lanatus (Thunb.) Matsum. \& Nakai] seedlings.

\section{MATERIAL AND METHODS}

\section{Plant material and stress treatments}

Seeds of arugula (Eruca sativa Miller, cv. Cultivada), carrot (Daucus carota L., cv. Nantes), eggplant (Solanum melongena L., cv. Embú) and watermelon [Citrullus lanatus (Thunb.) Matsum. \& Nakai cv. Crimson Sweet] were purchased from Horticeres Seeds Company, Indaiatuba, SP, Brazil and stored in the dark at $15{ }^{\circ} \mathrm{C}$ and $45 \% \mathrm{RH}$ until used for this experiment.

Seeds of each species were previously disinfected by immersion in a sodium hypochlorite solution, containing $2 \%(\mathrm{v} / \mathrm{v})$ of active chlorine, for 5 minutes (SAUER \& BURROUGHS, 1986). Seeds were then washed three times with distilled water, and subjected to four osmotic potential levels [0.0 (control); $-0.2 ;-0.4$; and $-0.8 \mathrm{MPa}$ ] induced by different concentrations of polyethylene glycol 6000 (PEG-6000) solutions. The concentrations of PEG6000 required to obtain these values were determined by using the equation of Michel \& Kaufmann (1973): $\Psi \mathrm{s}=\left[-\left(1.18 \times 10^{-2}\right) \mathrm{C}-(1.18 \times\right.$ $\left.10^{-4}\right) \times \mathrm{C}^{2}+\left(2.67 \times 10^{-4}\right) \mathrm{CT}+\left(8.39 \times 10^{-7}\right)$ $\left.\mathrm{C}^{2} \mathrm{~T}\right] / 10$, where $\Psi_{\mathrm{s}}=$ osmotic potential $(\mathrm{MPa}) ; \mathrm{C}=$ concentration ( $\mathrm{g} \mathrm{L}^{-1}$ PEG-6000 in water); $\mathrm{T}=$ temperature $\left({ }^{\circ} \mathrm{C}\right)$. As control, a solution with osmotic potential $\Psi \mathrm{s}=0.0 \mathrm{MPa}$ was used.

The treatments were arranged in a completely randomized design, in a $4 \times 4$ factorial arrangement, with four plant species (arugula, carrot, eggplant and watermelon) and four osmotic potentials $(0.0 ;-0.2 ;-0.4$; and $-0.8 \mathrm{MPa})$, with four replicates.

\section{Germination conditions}

Four replicates of 50 seeds from each species were evenly distributed in plastic boxes $(11.0 \times 11.0 \times 3.5 \mathrm{~cm}$, type Gerbox $)$ with blotter paper, properly moistened with different PEG solutions, in the proportion of 2.5 times the mass of dry paper. The boxes were then closed with lids to prevent evaporation and maintain the relative humidity close to $100 \%$. Germination was carried out in a germination chamber under $12 / 12 \mathrm{~h}$ photoperiod (light/darkness), light fluence of 60 umol $\mathrm{m}^{-2} \mathrm{~s}^{-1}$ photosynthetic photon flux density (PPFD) and temperature of $25^{\circ} \mathrm{C}$ for 14 days. Seeds were considered germinated when radicle were longer than $5.0 \mathrm{~mm}$. Germinated seeds were recorded every $24 \mathrm{~h}$ for 14 days.

\section{Measurements of germination and seedling growth}

The number of germinated seeds was recorded daily, and the final germination percentage was determined after 14 days. The germination rate index (GRI) was calculated using Maguire's equation (Maguire, 1962): GRI $=\Sigma\left(n_{\mathrm{i}} / t_{\mathrm{i}}\right)$, where $n_{\mathrm{i}}$ is the number of germinated seeds on a given day, and $t_{\mathrm{i}}$ is the time in days from the starting/sowing day (0). The mean germination time (MGT) was calculated using the equation of Labouriau (1983): MGT $=\left(\Sigma n_{\mathrm{i}} t_{\mathrm{i}}\right) / \Sigma n_{\mathrm{i}}$, where $n_{\mathrm{i}}$ is the number of germinated seeds on a given day, and $t_{\mathrm{i}}$ is the time in days from the starting/sowing day (0).

The shoot and radicle length were measured in 20 normal seedlings randomly obtained after count of the total germination $\left(14^{\text {th }}\right.$ day) using meter scale. The results were expressed in millimeter $(\mathrm{mm})$. For the determination of dry matter production of shoot and roots, all seedlings obtained at the end of the germination test (14 days) were separated into shoots and roots, dried in a forced air circulation oven for three days at $65^{\circ} \mathrm{C}$, and then weighed. The results were expressed in $\mathrm{mg}$ seedling $^{-1}$. To determine root: shoot ratio (RSR), root dry matter obtained was divided by the shoot dry matter.

The data of germination percentage, seedling length and dry matter production were used to calculate the seedling vigor and drought tolerance 
indices. Seedling weight and length vigor indices in each treatment was calculated using following equations, as suggested by Abdul-Baki and Anderson (1973): SLVI $=$ [seedling length $(\mathrm{cm}) \times$ seed germination $(\%)$ ] and SWVI $=$ [seedling dry weight $(\mathrm{mg}) \times$ seed germination $(\%)]$.

The drought tolerance index was calculated using the equation of Bouslama and Schapaugh (1984): YSI $=Y_{\mathrm{S}} / Y_{\mathrm{C}}$, where YSI is the yield stability index, $Y_{\mathrm{S}}$ and $Y_{\mathrm{C}}$ are the total dry matter yield (mg/seedling) under drought stress and nonstress conditions (control), respectively.

\section{Statistical analyses}

The normality of data was previously tested by the Kolmogorov-Smirnov test at the 5\% level and then data were submitted to analysis of variance (ANOVA), and means of plant species and osmotic potentials were compared by the Tukey test at the 0.05 level of confidence. For statistical analysis, the data expressed in percentage were previously transformed into $\arcsin \sqrt{x / 100}$. The analyses were performed using Sisvar version 5.3 software for Windows (Statistical Analysis Software, UFLA, Lavras, MG, BRA).

\section{RESULTS AND DISCUSSION}

The results of the analysis of variance showed significant effects $(P<0.01)$ for the main effects of plant species and osmotic potential levels, as well as for interaction between these factors, for all traits measured (Table 1). The significant interaction between the main effects of crops and osmotic potentials indicates that plant species have different response with regard to the level of drought stress. Such inference may be due to seed size, chemical composition of reserves, tegument permeability, hydration duration and activation of enzymatic reactions (BEWLEY et al., 2013).

Table 1. Summary of the analysis of variance for the measurements of germination, seedling growth inhibition and vigor indices of vegetable species as affected by drought stress.

\begin{tabular}{|c|c|c|c|c|c|c|c|c|c|c|c|}
\hline \multirow{2}{*}{$\begin{array}{c}\text { Causes of } \\
\text { variation }\end{array}$} & \multicolumn{11}{|c|}{ Probability $>\mathrm{F}$} \\
\hline & $\overline{\mathrm{GC}}$ & GRI & MGT & SL & RL & SDM & RDM & TDM & RSR & SLVI & SWVI \\
\hline Species (S) & $<0.000$ & $<0.000$ & $<0.000$ & $<0.000$ & $<0.000$ & $<0.000$ & $<0.000$ & $<0.000$ & $<0.000$ & $<0.000$ & $<0.000$ \\
\hline PEG (P) & $<0.000$ & $<0.000$ & $<0.000$ & $<0.000$ & $<0.000$ & $<0.000$ & $<0.000$ & $<0.000$ & $<0.000$ & $<0.000$ & $<0.000$ \\
\hline $\mathrm{S} \times \mathrm{P}$ & $<0.000$ & $<0.000$ & $<0.000$ & $<0.000$ & $<0.000$ & $<0.000$ & $<0.000$ & $<0.000$ & $<0.000$ & $<0.000$ & $<0.000$ \\
\hline$\overline{\mathrm{CV}}(\%)$ & 4.82 & 3.81 & 4.12 & 10.08 & 10.93 & 4.36 & 4.23 & 5.31 & 9.75 & 8.78 & 5.83 \\
\hline
\end{tabular}

GC: germination capacity. GRI: germination rate index. MGT: mean germination time. SL: shoot length. RL: radicle length. SDM: shoot dry matter. RDM: root dry matter. TDM: total dry matter. RSR: root: shoot ratio. SLVI: seedling length vigor index. SWVI: seedling weight vigor index.

\section{Effect of drought stress on seed germination}

The germination response of vegetable seeds was significantly affected by drought stress induced by PEG solutions (Figure 1A). When the seeds were exposed to highly negative osmotic potentials, germination capacity was drastically reduced. However, there were distinct responses among the vegetable crops with regard to the germination capacity under drought conditions. While the arugula seeds still showed germination capacity of up to $38 \%$ at $-0.8 \mathrm{MPa}$ osmotic potential, the seeds of eggplant and watermelon failed to germinate in this same stress condition. In turn, the germination of carrot seeds was completely inhibited at $-0.4 \mathrm{MPa}$ osmotic potential (Figure 1A). Additionally, arugula showed higher germination rate index (Figure 1B) and lower mean germination time (Figure 1C) in all osmotic potential levels compared to other three vegetable crops. These results suggest that arugula crop is more tolerant than carrot, eggplant and watermelon crops to drought stress during the seed germination phase.

Under drought stress, highly negative osmotic potential may affect the seeds water uptake, making germination not possible (MENESES et al., 2011). The most common responses of plants to reduction of osmotic potential are a delay in initial germination and a reduction in the rate and total germination (PEREIRA et al., 2009; SIKHA et al., 2013; GORDIN et al., 2015). Germination is a critical stage of the plant life and resistance against drought during the germination makes a uniform plant stand. Seeds of distinct species have different levels of starch and other food storage, which may be one factor with great influence on the expression of germination and seedling growth. Germination may be dependent on the ability of seed to utilize reserves more efficiently, by mobilization of seed reserves for germination traits (KESHAVARZ et al., 2013). Therefore, the use of species or genotypes with higher seed metabolic efficiency (SME) is a 
desirable character under water stress environment when emergence is delayed due to insufficient soil moisture.

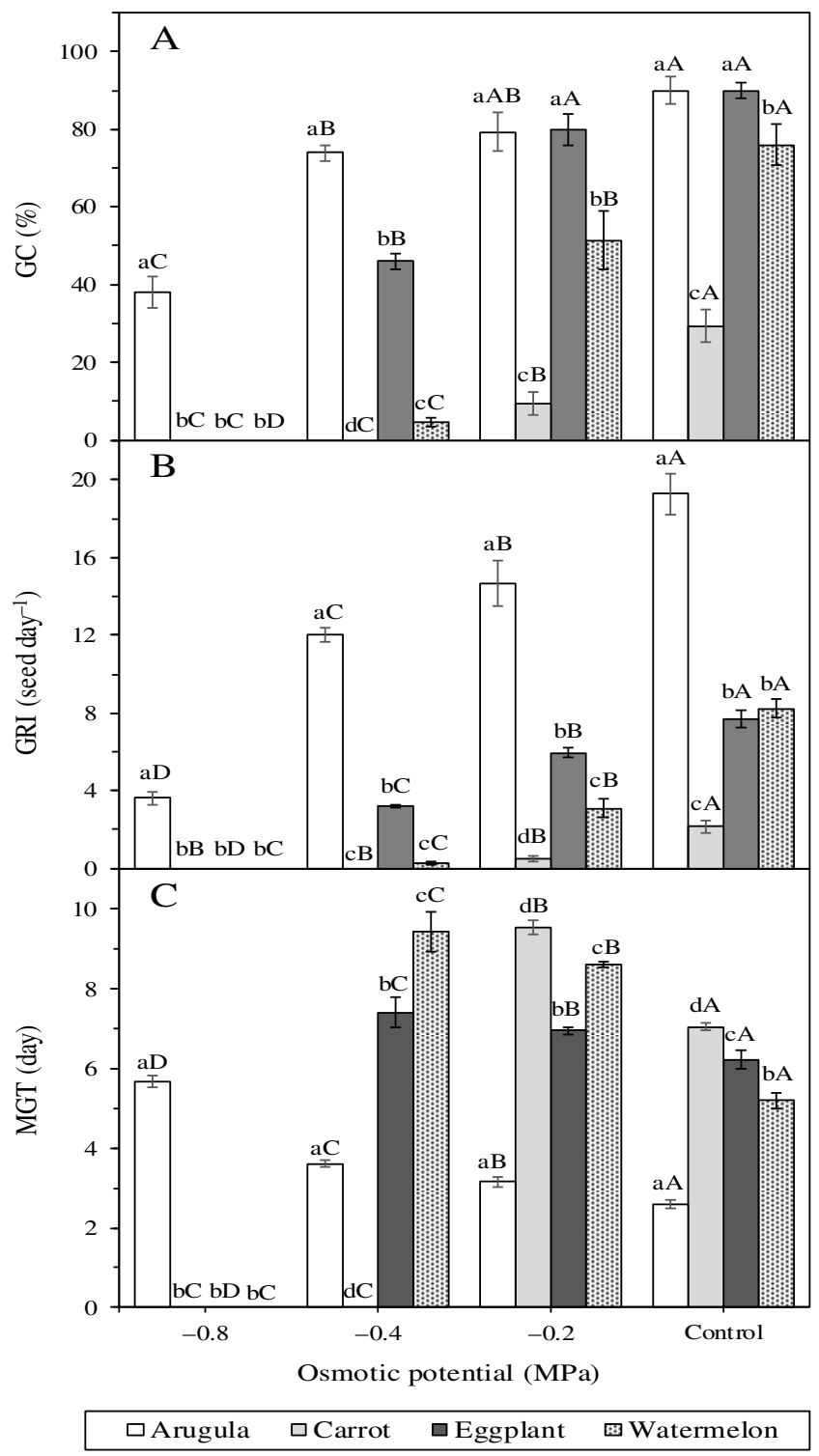

Figure 1. Effects of drought stress induced by polyethylene glycol on germination capacity (GC, in A), germination rate index (GRI, in B), and mean germination time (MGT, in C) of vegetable seeds. Bars followed by the same lower-case letters, between the vegetable species or same upper-case letters, for the osmotic potential levels within each species are not significantly different by Tukey test at the 0.05 level of confidence. Data refer to mean values $(n=4) \pm$ standard error.

The germination rate index (GRI) of arugula

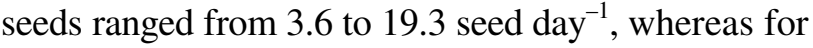
the other vegetable species of vegetables, the GRI ranged from 0.2 to 8.2 seed day $^{-1}$, and in all the vegetables it was drastically reduced with the rise of osmotic potential levels (Figure 1B). The decrease in index of germination rate was due to lower capacity of water uptake by the seeds with highly negative osmotic potential. Gharoobi et al. (2012) also reported that germination rate index and germination percentage of maize seeds, as well as the amount of water absorbed by seeds were considerably lowered with the rise of osmotic potential level. Drought stress affects the starch synthesis reactions and energy production process (adenosine triphosphate - ATP) through respiration (BEWLEY et al., 2013), resulting in reduced of germination percentage (Figure 1A), germination rate index (Figure 1B) and thus increasing the time for germination (Figure 1C).

The mean germination time (MGT) of arugula seeds was delayed by the lower osmotic potential $(-0.8 \mathrm{MPa})$ in more than 3 days (i.e., 2.6 to 5.7 days) compared with control treatment (Figure 
1C). For the seeds of eggplant and watermelon there was a delay of 1.2 and 4.2 days in the MGT for the $-0.6 \mathrm{MPa}$ osmotic potential, respectively, compared with control (Figure 1C). In turn, the $-0.4 \mathrm{MPa}$ osmotic potential delayed the MGT of carrot seeds in more than 2 days (i.e., 7.0 to 9.5 day) compared with control (Figure 1C). The MGT is a measure of the rate and time-spread of germination (BEWLEY et al., 2013). A delay in the mean time to germination may be disadvantageous for successful establishment, since the delayed germination leaving the seeds more vulnerable to attack from predators (pests and pathogens) and unfavorable environmental conditions (temperature, substrate moisture, among others) and, therefore, compromise the establishment of a uniform stand.

The delay in germination was due to lower water uptake of the seeds, which is the first step to occur germination process (i.e., imbibition). According to Bewley et al. (2013), it is necessary that the seeds reach an adequate level of hydration during the imbibition phase, to occur reactivation of seed metabolic processes and growth of embryonic axis. Seeds subjected to severe drought stress require more time to adjust the internal osmotic potential in accordance with the external environment (LUAN et al., 2014; GORDIN et al., 2015). Additionally, the osmotic potential of the external medium can affect the enzymatic reactions in the seed, therefore, the delay in germination is due to delay of enzymatic reactions (BEWLEY et al., 2013). The result of these changes is an unevenness in the germination process and stand establishment.

\section{Effect of drought stress on seedling growth}

The initial seedling growth of four vegetable crops was significantly affected by drought stress induced by PEG solutions (Figure 2). There was decrease in shoot and root related traits with the rise of osmotic potential levels. Under the osmotic stress of $-0.2,-0.4$ and $-0.8 \mathrm{MPa}$, shoot length of arugula decreased $23 \%, 56 \%$ and $92 \%$, respectively, while the shoot length of eggplant and watermelon seedlings decreased $38 \%$ and $88 \%$ at $-0.2 \mathrm{MPa}$ osmotic stress, and $77 \%$ and $99 \%$ at $-0.4 \mathrm{MPa}$ osmotic stress, respectively, compared to control (Figure 2A). For the carrot seedlings, the osmotic potential $-0.2 \mathrm{MPa}$ reduced the shoot length in $88 \%$. Primary root length of arugula, eggplant and watermelon under the osmotic stress of $-0.4 \mathrm{MPa}$ decreased $55 \%, 49 \%$ and $94 \%$, respectively, while the radicle length of carrot at $-0.2 \mathrm{MPa}$ osmotic potential decreased $57 \%$, respectively, compared to control (Figure 2B). This decrease in the growth rate of the seedlings could be due to a reduction in one or both of the primary cellular growth parameters: wall extensibility and cell turgor. Under drought stress conditions, seedling growth is affected due to the reduction of water uptake by the plants and lower cell turgor pressure (KERBAUY, 2012). Indeed, $\mathrm{Li}$ et al. (2011) reported a root growth rate from $27.8 \mathrm{~mm}$ day $^{-1}$ under well-watered conditions, whereas under drought stress conditions this root growth rate was only $16.1 \mathrm{~mm}^{-1 a y}{ }^{-1}$. According to Naeem et al. (2015), one of the first processes affected in response to low water availability is cell expansion, highly dependent process turgidity of the plants. As a result of these effects, there is a reduction in dry matter production of seedlings (Figure 2E). Morales et al. (2015) found that the reduction of water availability resulted in the lower number of leaves, plant height and dry matter production of tomato plants. Drought stress has been found to limit growth in several horticultural crops.

Root: shoot ratio (RSR) is one of several ratios, which give estimates of the distribution of dry matter between the different plant organs. It is a measure of the partitioning of dry matter between the shoots and the root systems, and is a good indicator for effects on root and shoot dry matter (KESHAVARZ et al., 2013). The results showed that RSR was increased with the rise of osmotic potential levels (Figure 2F). This suggests that shoot growth was affected more than the root system under drought stress. Such increase in RSR indicates that the proportion of dry matter allocated to shoots was decreased compared to the roots. Studies have shown that shoot is more likely to be affected by water stress than other traits, as reported by Zahedifar and Zohrabi (2016) for wheat seedlings. Assimilate partitioning is a complicated process that can be controlled simultaneously by sources and sinks. In general, plants exposed to high osmotic potential levels often partition photosynthate occurs preferentially to the roots, thereby maintaining a balance between processes required in roots (e.g.; water and nutrient uptake) and those required in shoots (e.g., photosynthesis).

Under severe stress conditions ( -0.4 and $0.8 \mathrm{MPa}$ ), arugula seedlings showed higher RSR compared to other vegetable species, whereas under mild stress (-0.2 MPa), carrot showed higher RSR (Figure 2F). These results indicate that the dry matter allocated to the roots was increased compared to that of the shoot of arugula and carrot seedlings under severe and mild stress conditions, respectively. During the plant establishment phase, the allocation of dry matter to the roots seems to be a protection mechanism for the crop tolerate a 
drought condition. Therefore, results presented here suggest that arugula is a more adapted species to a high-water restriction condition compared to other vegetable species. These results are also confirmed by the greater germination capacity of the arugula seeds under conditions of highly negative osmotic potential (Figure 1A).

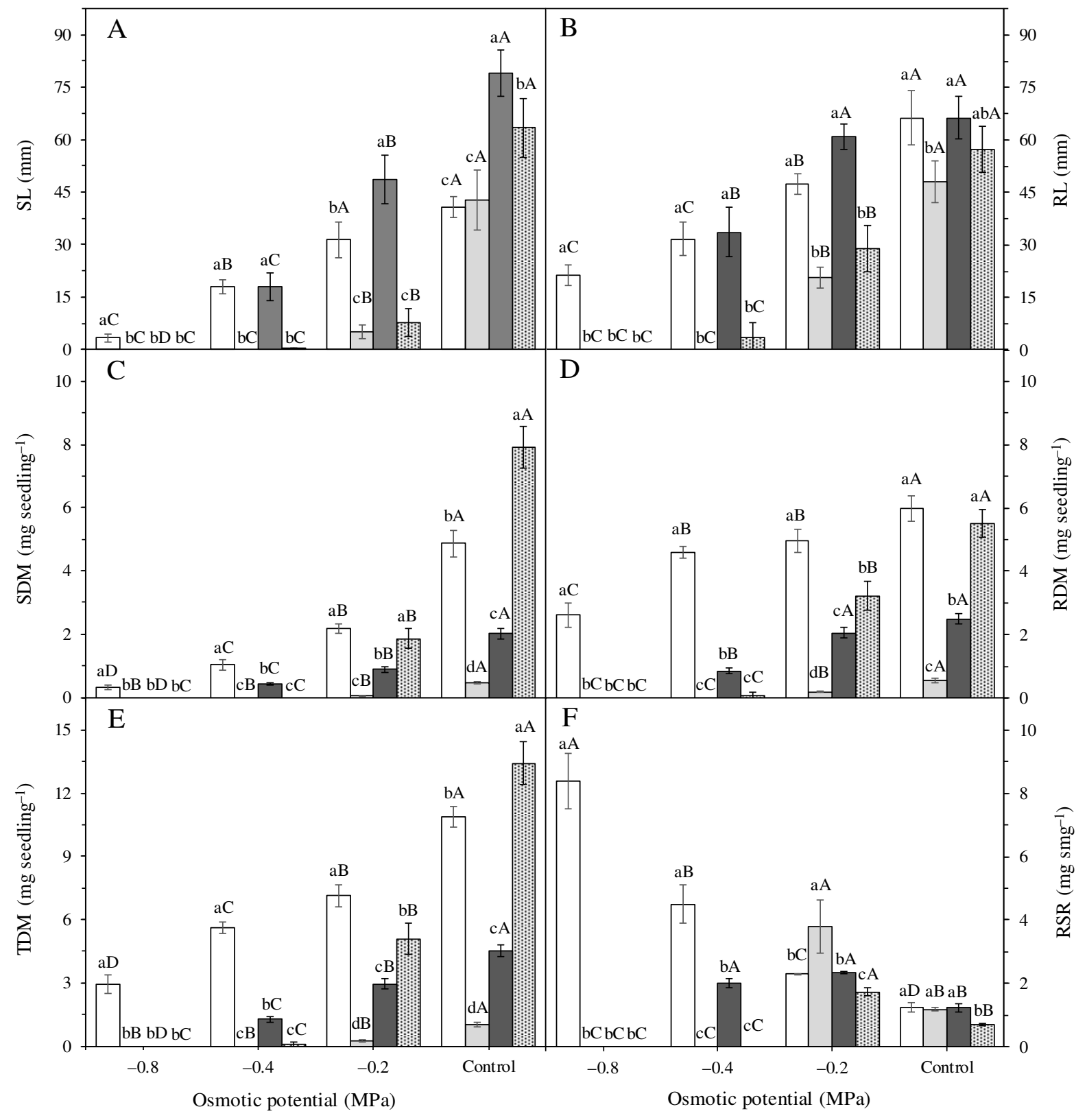

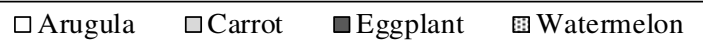

Figure 2. Effects of drought stress induced by polyethylene glycol on shoot length (SL, in A), radicle length (RL, in B), shoot dry matter (SDM, in C), root dry matter (RDM, in D), total dry matter (TDM, in E) and root: shoot ratio (RSR, in F) of vegetable seedlings. Bars followed by the same lower-case letters, between the vegetable species or same upper-case letters, for the osmotic potential levels within each species are not significantly different by Tukey test at the 0.05 level of confidence. Data refer to mean values $(n=4) \pm$ standard error.

The seedling length vigor index (SLVI) under conditions of adequate water availability was significantly higher for eggplant, followed by arugula and watermelon, and lower for carrot (Figure 3A). On the other hand, the seedling weight vigor index (SWVI) was significantly higher for arugula and watermelon, and lower for carrot (Figure 3B). Under drought stress conditions, arugula crop, in general, showed the highest values of seedling vigor indices compared to other 
vegetables at all osmotic potential levels, suggesting that this species is more tolerant than eggplant, watermelon and carrot to the negative effects of drought during the seedling establishment stage.
However, for the four vegetable crops both seedling vigor indexes were drastically reduced with the rise of osmotic potential levels (Figure 3).

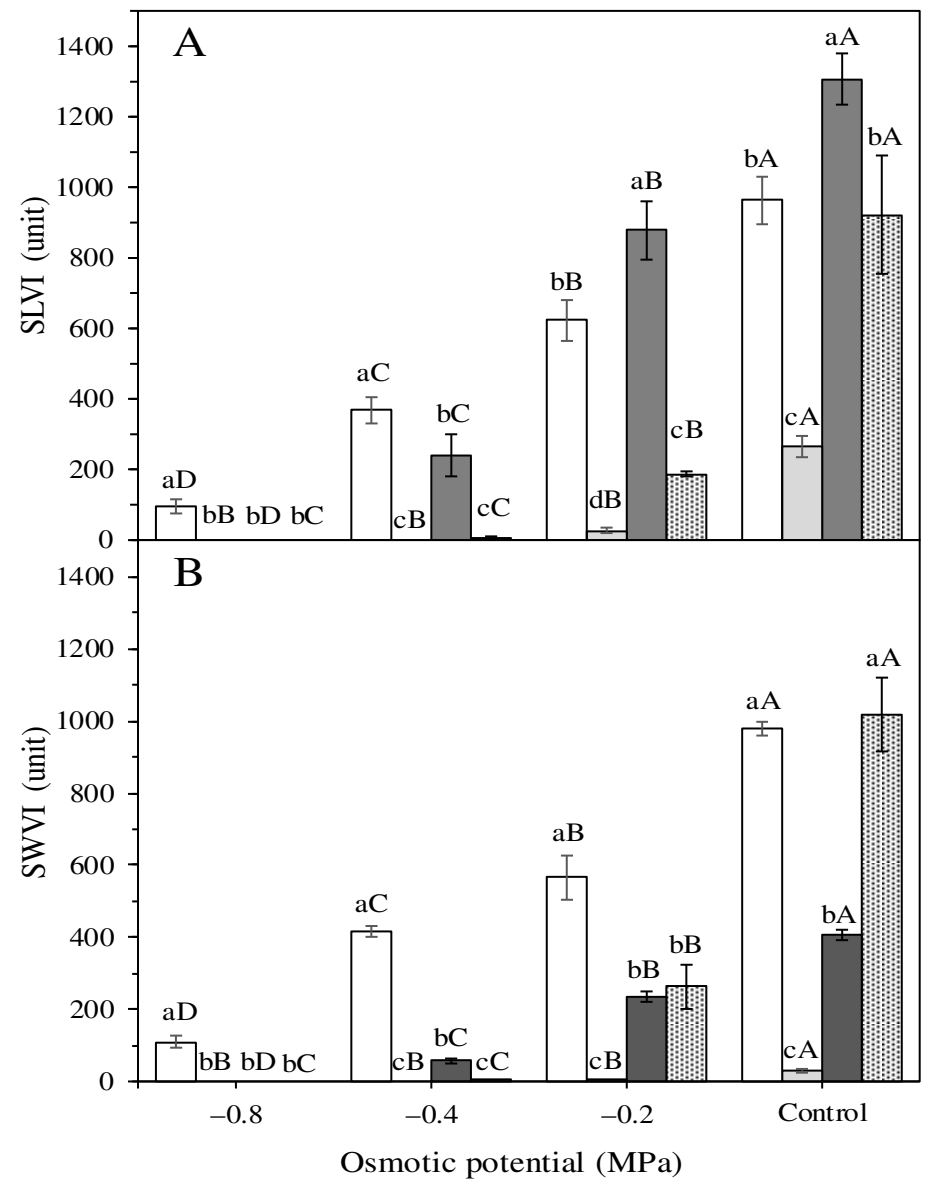

$\square$ Arugula $\square$ Carrot $\square$ Eggplant . Watermelon

Figure 3. Effects of drought stress induced by polyethylene glycol on seedling length vigor index (SLVI, in A) and weight vigor index (SWVI, in B) of four vegetable species. Bars followed by the same lower-case letters, between the vegetable species or same upper-case letters, for the osmotic potential levels within each species are not significantly different by Tukey test at the 0.05 level of confidence. Data refer to mean values $(n=4) \pm$ standard error.

The seedling vigor index has been used as a tolerance index to evaluate the effect of drought stress on seedling growth (ZAHEDIFAR; ZOHRABI, 2016). Seedling vigor is a measure of the extent of damage that accumulates as viability declines, and the damage accumulates in seeds until the seeds are unable to germinate and eventually die (BEWLEY et al., 2013). The lower seedling vigor index obtained with increased osmotic potential level was due to the drought stress reduce germination rate of seeds and inhibit the growth of plants, especially of the shoots. The reduction in vigor index of seedlings under water restriction conditions is usually reported by other research (GHAROOBI et al., 2012; AGUILAR-BENÍTEZ et al., 2014; ZAHEDIFAR; ZOHRABI, 2016).
The yield stability index (YSI) of four vegetable crops was significantly affected by drought stress induced by PEG solutions (Figure 4). Under $-0.2 \mathrm{MPa}$ osmotic potential, the YSI for the arugula, carrot, eggplant and watermelon were 0.66 , $0.26,0.65$ and 0.38 (Figure 4 ). These results indicate that in mild stress conditions the arugula and eggplant crops have similar drought tolerance indices. However, under conditions of severe stress $(-0.4$ and $-0.8 \mathrm{MPa})$, the drought tolerance index of the arugula was significantly higher compared to other vegetables. The YSI had been used to evaluate the stability of genotypes in the both stress and nonstress conditions and is considered a good drought tolerance index (BOUSLAMA; SCHAPAUGH, 1984). 


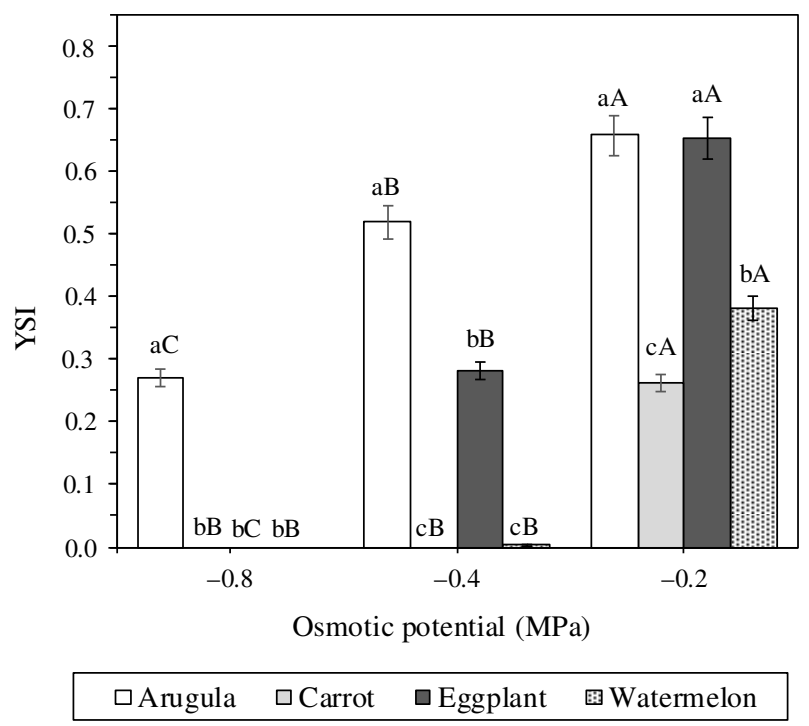

Figure 4. Effects of drought stress induced by polyethylene glycol on the yield stability index (YSI) of four vegetable species. Bars followed by the same lower-case letters, between the vegetable species or same upper-case letters, for the osmotic potential levels within each species are not significantly different by Tukey test at the 0.05 level of confidence. Data refer to mean values $(n=4) \pm$ standard error.

\section{CONCLUSIONS}

Carrot and watermelon are more susceptible than arugula and eggplant to drought stress, with germination response declining more rapidly with increasing osmotic potential level.

Arugula and eggplant crops tolerate water stress of up to $-0.2 \mathrm{MPa}$, without reducing germination of the seeds; however, the growth of shoots and roots are inhibited by the highly negative osmotic potential.

The germination process of eggplant and watermelon seeds are completely inhibited at -0.8 $\mathrm{MPa}$ osmotic potential, whereas germination of carrot seeds is completely inhibited at $-0.4 \mathrm{MPa}$ osmotic potential. Severe drought stress limits the process of seed germination and initial seedling growth of vegetable crops.

RESUMO: Sementes de rúcula (Eruca sativa Miller, cv. Cultivada), cenoura (Daucus carota L., cv. Nantes), berinjela (Solanum melongena L., cv. Embú) e melancia [Citrullus lanatus (Thunb.) Matsum. \& Nakai cv. Crimson Sweet] foram submetidas a diferentes potenciais osmóticos simulados com polietileno glicol (PEG 6000) com o objetivo de avaliar os efeitos do estresse hídrico na germinação e no crescimento inicial das plântulas. As sementes foram distribuídas em caixas plásticas tipo Gerbox ${ }^{\circledR}$ contendo papel mata-borrão, o qual foi umedecido com diferentes soluções de PEG preparadas com quatro níveis de potenciais osmótico [0 (controle); $-0,2 ;-0,4 ; \mathrm{e}-0,8 \mathrm{MPa}]$. As caixas plásticas foram então mantidas em câmara de germinação à 25 ${ }^{\circ} \mathrm{C}$ por 14 dias. $\mathrm{O}$ delineamento utilizado foi o inteiramente casualizado, em esquema fatorial $4 \times 4$, com quatro repetições de 50 sementes cada. Os resultados mostraram que o aumento do nível de potencial osmótico da solução reduziu a porcentagem de germinação das sementes, o índice de velocidade de germinação, o comprimentos da parte aérea e da raiz principal, a produção de matéria seca da parte aérea e das raízes e os índices de vigor das plântulas, enquanto que o tempo médio de germinação e a relação entre a matéria seca da raiz/parte aérea aumentou em todas as quatro espécies de hortaliças. As culturas de cenoura e melancia são mais susceptível que a rúcula e a berinjela ao estresse hídrico, com resposta de germinação declinando mais rapidamente com o aumento do nível de potencial osmótico. A rúcula e a berinjela toleram estresse hídrico de até - $0,2 \mathrm{MPa}$, sem reduzir o processo de germinação das sementes; no entanto, o crescimento da parte aérea e das raízes são inibidos. O processo de germinação das sementes de berinjela e melancia são completamente inibidos em potencial osmótico de $-0.8 \mathrm{MPa}$, ao passo que a germinação das sementes de cenoura é completamente inibida em potencial osmótico de $-0.4 \mathrm{MPa}$. O estresse hídrico severo limita o processo de germinação das sementes e crescimento inicial de plântulas das quatro espécies de hortaliças. 
PALAVRAS-CHAVE: Eruca sativa. Daucus carota. Solanum melongena. Citrullus lanatus. Potencial osmótico. PEG 6000.

\section{REFERENCES}

ABDUL-BAKI, A. A.; ANDERSON, J. D. Vigor determination in soybean by multiple criteria. Crop Science, Madison, v. 13, n. 6, p. 630-633, 1973.

https://doi.org/10.2135/cropsci1973.0011183x001300060013x

AGUILAR-BENÍTEZ, G.; PEÑA-VALDIVIA, C. B.; VEJA, J. R.; CASTRO-RIVERA, R.; RAMÍREZ-

TOBÍAS, H. M. Seed germination and early root growth in common bean and maize landraces and improved cultivars at different water stress levels. International Journal of Applied Science and Technology, v. 4, n. 4, p.118-127, 2014.

BASHA, P. O.; SUDARSANAM, G.; REDDY, M. M. S.; SANKAR, N. S. Effect of PEG induced water stress on germination and seedling development of tomato germplasm. International Journal of Recent Scientific Research, v. 6, n. 5, p. 4044-4049, 2015.

BEWLEY, J. D.; BRADFORD, K.; HILHORST, H.; NONOGAKI, H. Seeds: Physiology of Development, Germination and Dormancy. $3^{\text {rd }}$ ed. New York: Springer. 2013. 392p. https://doi.org/10.1007/978-1-46144693-4

BOUSLAMA, M.; SCHAPAUGH, W. T. Stress tolerance in soybean. Part 1: evaluation of three screening techniques for heat and drought tolerance. Crop Science, Madison, v. 24, p. 933-937, 1984.

https://doi.org/10.2135/cropsci1984.0011183x002400050026x

GEORGE, S.; JATOI, S. A.; SIDDIQUI, S. U. Genotypic differences against PEG simulated drought stress in tomato. Pakistan Journal of Botany, Carachi, v. 45, n. 5, p. 1551-1556, 2013.

GHAROOBI, B.; GHORBANI, M.; GHASEMI, N. M. Effects of different levels of osmotic potential on germination percentage and germination rate of barley, corn and canola. Iranian Journal of Plant Physiology, v. 2, n. 2, p. 413-417, 2012.

GORDIN, C. R. B.; SCALON, S. P. Q.; MASETTO, T. E. Disponibilidade hídrica do substrato e teor de água da semente na germinação de niger. Pesquisa Agropecuária Tropical, Goiânia, v. 45, n. 3, p. 312-318, 2015. https://doi.org/10.1590/1983-40632015v4535337

HU, X.W.; FAN, Y.; BASKIN, C. C.; BASKIN, J. M.; WANG, Y. R. Comparison of the effects of temperature and water potential on seed germination of Fabaceae species from desert and subalpine grassland. American Journal of Botany, Saint Louis, v. 102, n. 5, p. 649-660, 2015. https://doi.org/10.3732/ajb.1400507

JATOI, S. A.; LATIF, M. M.; ARIF, M.; AHSON, M.; KHAN, A.; SIDDIQUI, S. U. Comparative assessment of wheat landraces against polyethylene glycol simulated drought stress. Science Technology and

Development, Islamabad, v. 33, p. 1-6, 2014.

KERBAUY, G. B. Fisiologia Vegetal. 2 ed. Guanabara Koogan: Rio de Janeiro. 2012. 431p.

KESHAVARZ, R.; KEIKHAH, M.; CHAICHI, M. R.; ANSARI, M. Effect of different levels of salinity and drought stress on seed germination characteristics and seedling growth of forage turnip (Brassica rapa $\mathrm{L}$.). Iranian Journal of Field and Crop Science, v. 43, n. 4, p. 661-671, 2013. 
LABOURIAU, L. G. A germinação de sementes. Washington: Organização dos Estados Americanos, 1983. $174 \mathrm{p}$.

LI, F. L.; BAO, W. K.; WU, N. Morphological, anatomical and physiological responses of Campylotropis polyantha (Franch.) Schindl. seedlings to progressive water stress. Scientia Horticulturae, Netherlands, v. 127, n. e, p. 436-443, 2011.

https://doi.org/10.1016/j.scienta.2010.10.017

LUAN, Z.; XIAO, M.; ZHOU, D.; ZHANG, H.; TIAN, Y.; WU, Y.; GUAN, B.; SONG, Y. Effects of salinity, temperature, and polyethylene glycol on the seed germination of sunflower (Helianthus annuus L.). The

Scientific World Journal, v. 2014, Article ID 170418, 9p. 2014. https://doi.org/10.1155/2014/170418

MAGUIRE, J. D. Speed of germination - aid in selection and evaluation for seedling emergence and vigor.

Crop Science, Madison, v. 2, n. 1, p.176-177, 1962.

https://doi.org/10.2135/cropsci1962.0011183X000200020033x

MEDEIROS, D. S.; ALVES, E. U.; SENA, D. V. A.; SILVA, E. O.; ARAÚJO, L. R. Desempenho fisiológico de sementes de gergelim submetidas a estresse hídrico em diferentes temperaturas. Semina: Ciências

Agrárias, Londrina, v. 36, n. 5, p. 3069-3076, 2015. https://doi.org/10.5433/1679-0359.2015v36n5p3069-3076

MENESES, C. H. S. G.; BRUNO, R. L. A.; FERNANDES, P. D.; PEREIRA, W. E.; LIMA, L. H. G. M.; LIMA, M. M. A.; VIDAL, M. S. Germination of cotton cultivar seeds under water stress induced by polyethyleneglycol-6000. Scientia Agricola, Piracicaba, v. 68, n. 2, p. 131-138, 2011.

https://doi.org/10.1590/s0103-90162011000200001

MICHEL, B. E.; KAUFMANN, M. R. The osmotic potential of polyethylene glycol 6000. Plant Physiology, Lancaster, v. 51, n. 5, p. 914-916, 1973. https://doi.org/10.1104/pp.51.5.914

MORALES, R. G. F.; RESENDE, L. V.; BORDINI, I. C.; GALVÃO, A. G.; REZENDE, F. C. Caracterização do tomateiro submetido ao déficit hídrico. Scientia Agraria, Curitiba, v. v.16, n.1, p. 9-17, 2015.

https://doi.org/10.5380/rsa.v16i1.41042

MUSCOLO, A.; SIDARI, M.; ANASTASI, U.; SANTONOCETO, C.; MAGGIO, A. Effect of PEG-induced drought stress on seed germination of four lentil genotypes. Journal of Plant Interactions, v. 9, n. 1, 2014. https://doi.org/10.1080/17429145.2013.835880

NAEEM, M. K.; AHMAD, M.; KAMRAN, M.; SHAH, M. K. N.; IQBAL, M. S. Physiological responses of wheat (Triticum aestivum L.) to drought stress. International Journal of Plant \& Soil Science, v. 6, n. 1, p. 19, 2015. https://doi.org/10.9734/ijpss/2015/9587

SAUER, D.B.; BURROUGHS, R. Disinfection of seed surfaces with sodium hypochlorite. Phytopathology, v. 76, n. 7, p. 745-749, 1986. https://doi.org/10.1094/Phyto-76-745

SIKHA, S.; SUNIL, P.; ARTI, J.; SUJATA, B. Impact of water-deficit and salinity stress on seed germination and seedling growth of Capsicum annuum 'Solan Bharpur'. International Research Journal of Biological Sciences, v. 2, n. 8, p. 9-15, 2013.

ZAHEDIFAR, M.; ZOHRABI, S. Germination and seedling characteristics of drought-stressed corn seed as influenced by seed priming with potassium nano-chelate and sulfate fertilizers. Acta Agriculturae Slovenica, v. 107, n. 1, p. 113-128, 2016. https://doi.org/10.14720/aas.2016.107.1.12 